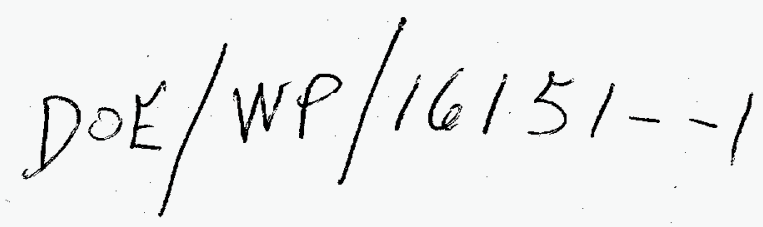

\title{
ANNUAL SITE ENVIRONMENTAL REPORT FOR CALENDAR YEAR 1986
}

\author{
Western Area Power Administration \\ 1627 Cole Boulevard \\ Golden, Colorado 80401
}

\section{DISCLAIMER}

This report was prepared as an account of work sponsored by an agency of the United States Government. Neither the United States Government nor any agency thereof, nor any of their employees, makes any warranty, express or implied, or assumes any legal liability or responsibility for the accuracy, completeness, or usefulness of any information, apparatus, product, or process disclosed, or represents that its use would not infringe privately owned rights. Reference herein to any specific commercial product, process, or service by trade name, trademark, manufacturer, or otherwise does not necessarily constitute or imply its endorsement, recommendation, or favoring by the United States Government or any agency thereof. The views and opinions of authors expressed herein do not necessarily state or reflect those of the United States Government or any agency thereof.

May 1987

Prepared By:

J.F. Sato and Associates

1667 Cole Boulevard, Suite 285

Golden, Colorado 80401

$\operatorname{IQE} / W F / 16151--1$ 


\section{PREFACE}

The Western Area Power Administration has established an effective formal environmental protection, auditing, and monitoring program which has been in effect since 1978. This annual site environmental report discusses the significant environmental projects and issues Western was involved with in 1986, and it is written to demonstrate the nature and effectiveness of the environmental protection program.

Department of Energy Order 5481.1, Chapter 3, requires the preparation of annual site environmental monitoring reports. Western has numerous facilities located in fifteen states. This report was written to address all of the facilities. 


\section{TABLE OF CONTENTS}

List of Figures

List of Tables

List of Abbreviations and Symbols

1.0 Introduction

2.0 Summary

3.0 Environmental Program Information

3.I Environmental Protection and Compliance

Hazardous and Toxic Materials

Pesticide Use

Water Pollution Control

Environmental Auditing Program

State and Local Environmental Requirements

3.2 Cultural Resources

3.3 Environmental Planning Activities and Research Projects

Special Environmental Activities and Research

Environmental Planning Permits

\section{APPENDICES}
A Miles City Converter Station Water Monitoring Data
B Standard Mitigative Practices (Western)
References
Distribution List 


\section{LIST OF FIGURES}

1. Marketing Area Map

\section{LIST OF TABLES}

1. List of Environmental Permits, Notices, and Orders

2. Reported Hazardous Material or Oil Spills

3. Environmental Impact Statements and Environmental Assessments for CY 1986

4. Special Mitigation Measures Implemented by Western for National Environmental Protection Act Compliance and Fish and Wildlife Coordination Act Compliance

5. Projects Ongoing in CY 1986 


\section{LIST OF ABBREVIATIONS AND SYMBOLS}

BAO - Billings Area Office

BCAO - Boulder City Area Office

BuRec - Bureau of Reclamation

BWC - International Boundary and Water Commission

CERCLA - Comprehensive Environmental Response Compensation and Liability Act

$C E Q$ - Council on Environmental Quality

CFR - Code of Federal Regulations

CRC - Cultural Resource Compliance

CY - Calendar Year

DOE - Department of Energy

EA - Environmental Assessment

EIS - Environmental Impact Statement

EPA - Environmental Protection Agency.

FIFRA - Federal Insecticide, Fungicide, and Rodenticide Act

HVDC - High Voltage Direct Current

LAO - Loveland Area Office

NEPA - National Environmental Policy Act

NPL - National Priorities List

PCB - Polychlorinated Biphenyls

RCRA - Resource Conservation and Recovery Act

SAO - Sacramento Area Office

SARA - Superfund Amendments and Reauthorization Act

SLCAO - Salt Lake City Area Office

TL - Transmission Line

TSCA - Toxic Substances Control Act 


\subsection{INTRODUCTION}

The Western Area Power Administration (Western) was established on December 21, 1977, pursuant to Section 302 of Public Law 95-91, the Department of Energy Organization Act, dated August 1, 1977. Western is responsible for the Federal electric power marketing and transmission functions in 15 central and western states encompassing a 1.3-million-square-mile geographic area. Western sells power to 567 customers consisting of cooperatives, municipalities, public utility districts, private utilities, Federal and State agencies, irrigation districts, and project use customers. The wholesale power customers, in turn, provide service to millions of retail consumers in the States of California, Nevada, Montana, Arizona, Utah, New Mexico, Texas, North Dakota, South Dakota, lowa, Colorado, Wyoming, Minnesota, Nebraska, and Kansas. Western is responsible for the operation and maintenance of 16,119 miles of transmission lines, 234 substations, and various appurtenant power facilities in the above geographic areas and also for planning, construction, and operation and maintenance of additional Federal transmission facilities that may be authorized in the future. Electric power marketed by Western is generated by the Bureau of Reclamation (BuRec), the U.S. Army Corps of Engineers (Corps), and the International Boundary and Water Commission (BWC) U.S. Section, which operate 49 hydropower generating plants in our service area. Additionally, Western markets the United States entitlement from the large Navajo coal-fired plant near Page, Arizona and power generated at a wind farm in Wyoming. Current installed generating capacity that Western markets is 9,648 megawatts (MW). 
In carrying out the Federal power marketing program, Western's organization consists of the Headquarters Office located in Golden, Colorado, and five Area Offices located in Billings, Montana; Boulder City, Nevada; Loveland, Colorado; Sacramento, California; and Salt Lake City, Utah. Additionally, there are five District Offices and one Power Systems Operations Office. The Western marketing area is shown on Figure I. Western, through its power marketing program, must secure revenues sufficient to meet the annual costs of operation and maintenance of the generating and transmission facilities; purchased power; wheeling and other expenses; and repay within allowable time periods, all of the power investment with interest and that portion of the Government's irrigation and other nonpower investments that are beyond the water users' repayment capability. 


\section{WESTERN AREA POWER ADMINISTRATION MARKETING AREA}

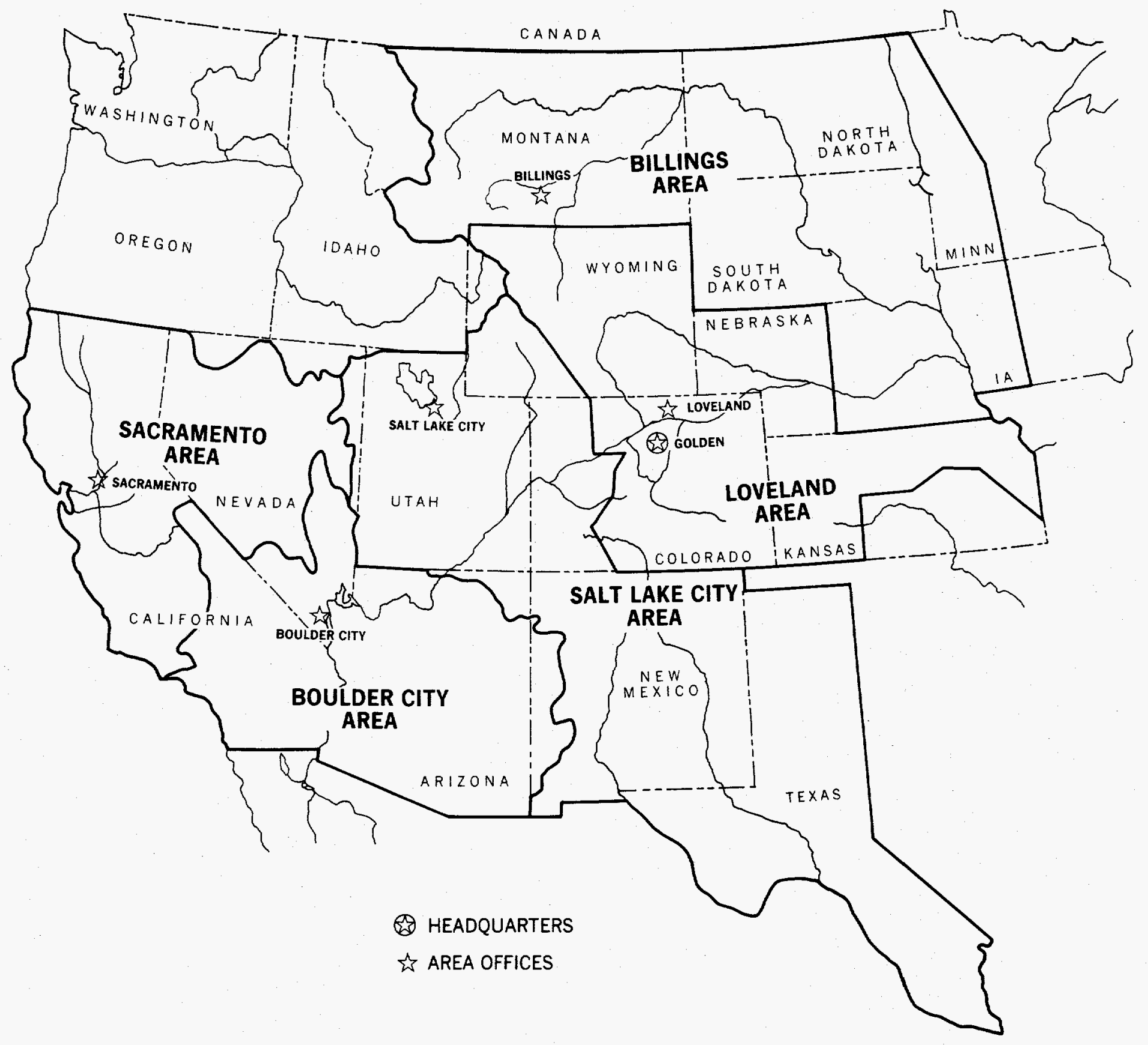




\subsection{SUMMARY}

Environmental protection regulations adopted during 1986 and predicted for the future show increased application to Western facilities. The challenge for effective environmental management under these increased requirements is being met by incorporation of procedures that improve ef ficiency and responsiveness.

The laws and regulations that apply to Western are vast and complex. Facilities are located in areas under the jurisdiction of several Environmental Protection Agency (EPA) regions and states. To help assure total responsibility to all regulatory requirements, Western has in place a firmly established and proven environmental protection compliance audit program. This program enables visits by knowledgeable personnel to many facilities on a regular basis to locate problems and provide remedies.

Polychlorinated biphenyls (PCBs) continue to be a major portion of the compliance program. $P C B$ material is increasingly regulated as more stringent State and Federal requirements are set. Western's policy is to eliminate PCBs wherever economically and operationally possible. The recent trend within Western is to combine PCB removal from various widespread locations to minimize procurement expense and maximize contractor efficiency. New technologies mean that the job of $\mathrm{PCB}$ removal and destruction can be done more efficiently and inexpensively than in the past. 
Electrical effects of alternating current (AC) and direct current (DC) power transmission remain a concern in the decisionmaking process under the National Environmental Policy Act (NEPA). Research to date has shown little or no reason for concern at the lower transmission voltages. New designs to improve transmission capacity and efficiency include the use of higher voltage $A C$ and DC power transmission. Western monitors the research efforts underway in these areas and is a participant in a study of high voltage DC effects on cattle and crops coordinated by Bonneville Power Administration.

Throughout 1986, Western's environmental planning continued to focus on increasing public and agency involvement early in the planning process. This shift was due, in part, to amended DOE Guidelines for Compliance with NEPA. Greater emphasis on early scoping of environmental issues to identify significant impacts was the focus of the DOE amended guidelines.

Emphasis on pre-scoping, coupled with a higher level of public and agency participation in project development, is enabling Western to better determine the appropriate level of environmental documentation. At the same time, it is possible to identify significant actions and relevant issues requiring a higher level of detailed analysis.

Larger scale projects and projects with a high potential for significant environmental impact are analyzed within environmental assessments and impact statements. However, the majority of Western's projects, with appropriate planning and mitigation, result in minimal environmental impacts. These projects 
are analyzed and cleared at a lesser level of documentation, requiring little time and paperwork and resulting in increased efficiency.

Earlier and more comprehensive official participation by the Advisory Council on Historic Preservation is streamlining cultural resource compliance activities. Increasing the level of monitoring of project implementation through public and agency feedback is helping to improve planning methods for the future. 


\subsection{ENVIRONMENTAL PROGRAM INFORMATION}

The Western environmental program is divided into three major categories: environmental protection and compliance; cultural resource protection; and compliance with environmental planning, siting, and mitigation requirements. Actions and activities taken by Western in each of these categories are discussed in the following sections.

\subsection{ENVIRONMENTAL PROTECTION AND COMPLIANCE}

The Resource Conservation and Recovery Act (RCRA), the Toxic Substances Control Act (TSCA), and the Comprehensive Environmental Response, Compensation, and Liability Act (CERCLA) continue to be the primary sources of regulatory actions for hazardous and toxic materials by the EPA, but several other Federal environmental laws have also resulted in regulations applicable to Western. These include the Federal Insecticide, Fungicide, and Rodenticide Act, and the Clean Water Act.

Western is required to obtain permits, licenses, or enter into interagency agreements that allow proceeding with environmentally regulated projects. In addition to the environmental permits, orders, and notices issued to Western, contractors who work for Western are required by contract to obtain required clearances and permits before commencing work. Maintenance, monitoring, and reporting related to the permits issued to the contractors is the responsibility of the contractor. 


\section{HAZARDOUS AND TOXIC MATERIALS}

Federal, State, and local governments have been actively expanding the scope of controls and requirements for the generation, handling, and disposal of hazardous and toxic wastes. Many states and localities have instituted measures that are more stringent than those of the Federal government. Increasingly, hazardous waste regulations are becoming applicable to Western.

In 1986, numerous regulations were either proposed or finalized that resulted from the enactment of the Hazardous and Solid Waste Amendments of 1984 (HWSA). HSWA-based regulations have impacted Western in many ways, with the most significant being the classification of some facilities as small quantity generators of hazardous waste. Also, the prohibition for landfilling liquids, dioxin-containing wastes, and many solvents is expected to have a long-term effect on some facilities.

\section{Underground Storage Tanks}

HWSA required, in part, that the owners or operators of underground storage tanks must notify designated State agencies if the tanks are used for storage of hazardous materials--including petroleum products. Reports were filed for all Area Offices for which reports were needed before the May 8, 1986, deadline. Monitoring or testing of most existing underground tanks is required in a staged program under HSWA, and the Area Office staffs have started or will soon begin this work. 
In 1986, permits were obtained from several California counties to allow Western to operate fuel storage tanks. The permits currently require quarterly reporting of the volume of material in the tanks. In a phased approach to take place over several years, the tanks must be monitored for leakage by installation of leak detecting equipment. Permits were also obtained in 1986 from two counties in California to allow removal of unneeded petroleum storage tanks. Table I provides information on the tank permits.

\section{PCB Use and Disposal}

The Western environmental staff's ongoing coordination of the removal and proper disposal of PCBs from facilities continued during 1986. An agency-wide PCB disposal contract was awarded to ensure consistent and proper handling. The contracted disposal firm is also required to transport the PCBs and prepare the necessary paperwork including certificates of destruction or disposal.

The program of environmental auditing of many of the facilities that use or store PCBs was conducted as it has been in the past several years. The purpose of the audits is to advise the facilities as to the applicability of current regulations to their particular operations, review records, point out areas of non-compliance, and call attention to practices that are at variance with industry environmental standards. Audits are also used to provide on-site assistance including discussion of options which are available for compliance. 
TABLE I

LIST OF ENVIRONMENTAL PERMITS, NOTICES, AND ORDERS

\begin{tabular}{|c|c|c|c|c|}
\hline NAME & ISSUING AGENCY & STATUS & $\begin{array}{l}\text { EXPIRATION } \\
\text { DATE }\end{array}$ & COMMENTS \\
\hline $\begin{array}{l}404 \text { Permit - } \\
\text { Nationwide }\end{array}$ & U.S. Army Corps & Ongoing & None & Section 323.t \\
\hline $\begin{array}{l}\text { Hazardous Waste } \\
\text { Hauler Register } \\
\text { Permit }\end{array}$ & State of California & $\begin{array}{l}\text { Renewed } \\
8 / 86\end{array}$ & $8 / 87$ & \\
\hline $\begin{array}{l}\text { Permit for Under- } \\
\text { ground Tank } \\
\text { Removal }\end{array}$ & $\begin{array}{l}\text { (1) Shasta, CA } \\
\text { (2) Sacramento, CA }\end{array}$ & $\begin{array}{l}8 / 86 \\
5 / 86\end{array}$ & & $\begin{array}{l}\text { Regulated by } \\
\text { State }\end{array}$ \\
\hline $\begin{array}{l}\text { Permit to Operate } \\
\text { Underground } \\
\text { Storage Tanks }\end{array}$ & $\begin{array}{l}\text { (3) Shasta, CA } \\
\text { (4) Sacramento, CA }\end{array}$ & $\begin{array}{l}3 / 86 \\
3 / 86\end{array}$ & & Filed \\
\hline $\begin{array}{l}\text { Water Quality } \\
\text { Permit, Miles } \\
\text { City Converter }\end{array}$ & State of Montana & Ongoing & None & \\
\hline $\begin{array}{l}\text { Permit to Operate } \\
\text { Underground } \\
\text { Storage Tanks }\end{array}$ & State of Arizona & $\begin{array}{l}\text { Renewed } \\
3 / 86\end{array}$ & $3 / 87$ & \\
\hline
\end{tabular}


Hazardous Material Handling and Disposal

The majority of hazardous and toxic wastes transported for Western are shipped via contracted-commercial haulers. However, Western employees occasionally transport hazardous or toxic wastes from the point of generation to storage facilities. Federal hazardous material transportation regulations were modified in 1986: - reportable quantities changed, the Department of Transportation (DOT) adopted EPA's CERCLA list of hazardous materials, and hazardous waste manifest forms and labeling requirements were revised.

The California Department of Health Services has hazardous waste transportation requirements that are more extensive than those of DOT. Therefore, the Sacramento Area Office (SAO) and Boulder City Area Office (BCAO) must have a California waste hauler's permit for the transportation of PCBs. In 1986, the permit and a corresponding variance for vehicle inspections and insurance were renewed. The annual report on quantities shipped was submitted to the State as required by the permit.

The State of California also requires that persons or organizations that dispose of "extremely hazardous wastes" (as defined by the State) must obtain a permit on a case-by-case basis. Because California regulates PCBs at a concentration of greater than 5,000 ppm as an extremely hazardous waste, the SAO obtained permits in 1986 for several disposal actions. 
Congress has made clear its intent to encourage minimization of hazardous waste production by private and public generators. This goal is being achieved in Western on several fronts. Primarily, hazardous waste minimization is controlled by the reduced use of hazardous materials. Smaller amounts of hazardous materials such as solvents are being used. Materials that are non-toxic or have reduced toxicity are being substituted, whenever possible, for more hazardous materials. For example, most of the wood preservatives used for treating wooden transmission line structures are classified by EPA as being hazardous wastes if they are spilled, discarded, or not used for their intended purpose. Western has issued recommendations to substitute a product that is not listed as hazardous for the wood preservative currently in wide-spread use. Several major purchases of replacement wood poles which were treated with copper rapthenate (a less toxic and less regulated substance) were made in 1986. Employees are being informed as to the desirability of using alternate, less regulated solvents, degreasers, corrosion inhibitors, and other substances. Reducing the amount used of potential hazardous wastes is being encouraged.

Hazardous materials spills were reported to the responsible Federal and State agencies for several separate incidents. These minor spills were cleaned up immediately and resulted in insignificant environmental damage. The spills occurred at the locations shown in Table 2. All spills were contained within site boundaries, and the contaminated soil and equipment were disposed of or decontaminated as required by TSCA or RCRA. 
TABLE 2

REPORTED HAZARDOUS MATERIAL OR OIL SPILLS

\section{FACILITY}

Flagstaff Substation

Loveland Storage and Maintenance Facility

Hoyt Substation

Folsom Substation

\section{LOCATION}

$A Z$

$\mathrm{CO}$

$\mathrm{CO}$

$\mathrm{CA}$
SPILLED SUBSTANCE

PCB-containing Dielectric Fluid

Dielectric Fluid (Mineral Oil)

$\mathrm{PCB}$-containing Dielectric Fluid

Dielectric Fluid (Mineral Oil) 
Western does not have any sites listed on the National Priority List (NPL). From information currently available, it does not appear that Western owns any sites that are eligible for listing.

Congress passed the Superfund Amendments and Reauthorization Act (SARA) of 1986, which revised and expanded CERCLA. Many of the revisions apply to Western or could apply under certain circumstances. For example, hazardous material spills, natural resource damage assessments, and cleanup standards.

Of primary concern under SARA are the requirements in Title III for emergency planning and community right-to-know. Although Western's responsibilities under this title were not completely defined by the end of 1986, it is anticipated that full compliance with the law will be required and result in a major effort and use of resources in 1987 and 1988.

\section{PESTICIDE USE}

The regulations resulting from FIFRA that pertain to proper use and application of pesticides are applicable to Western. Western is an end user--not a producer--of pesticides. Pesticides are used by Western to control weeds, for wood preservation, and small amounts are used for rodent control. In 1986, environmental audits showed that Western remained substantially in compliance with the applicable regulations; no orders or other actions resulting from misuse or misapplication of pesticides were issued to Western by any enforcement agency in 1986. 


\section{WATER POLLUTION CONTROL}

The facilities Western owns and operates are exempt for the most part from regulation by the Clean Water Act and other water pollution control laws and statutes, because they do not generate effluents except for storm-water runoff which is currently not regulated. However, some facilities are regulated, and a summary of them follows.

\section{Miles City Converter Station}

The Miles City Converter Station, located in Montana, holds a water pollution control permit from the State of Montana and is required to conduct a quarterly groundwater monitoring program for the on-site evaporation pond. This is an

alternating current to direct current converter facility. The permit is required under A.R.M. 16.20.1017, and it expires May 31, 1994. Coolant discharge water contains low concentrations of a corrosion inhibitor, an antifoaming agent, and sodium hypochlorite. It is discharged to an on-site evaporation pond.

The permit requires quarterly monitoring of three groundwater monitoring wells for the following parameters:

- specific conductance (umhos/cm @ 25 C)

- ethylene glycol $(\mathrm{mg} / \mathrm{l})$ 
- corrosion inhibitor $(\mathrm{mg} / \mathrm{l})$

- static water level (tenths of feet below datum)

The results of the 1986 monitoring are included in Appendix A.

Spill Prevention, Control, and Countermeasure Plans

Preparation and implementation of spill prevention, control, and countermeasure plans are required for some of Western's facilities that have oil storage capacity in amounts exceeding the regulatory threshold. The plans must be reviewed every three years and recertified by a registered professional engineer. Several facility SPCC plans were reviewed and recertified in 1986.

Water pollution control regulations found at 40 CFR 112 also provide guidelines for construction of structures to prevent spilled oil from reaching navigable waters. Western considers these guidelines when designing new facilities or refurbishing of some existing substations. Containment structures were designed or constructed for eight facilities in 1986. 


\section{ENVIRONMENTAL AUDITING PROGRAM}

Western established a strong environmental auditing program in 1980 that has continued to provide effective and timely results. The major purposes of the auditing program are as follows:

- discover noncompliance with applicable local, state, and Federal regulations

- reduce environmental risks

- allow for communication with facility personnel

- improve overall environmental performance

- provide assistance and discuss compliance alternatives for problem areas

- accelerate development of environmental management

- provide for worker safety when working with hazardous wastes

- provide management with a fool for assessing and prioritizing compliance issues.

In 1986, over 40 facilities were audited by contracted auditors. The audited facilities were of several types including substations, maintenance facilities, and storage yards. 
Formal audit reports are prepared for each audit to outline the problems found and call attention to potential problems noted by the auditors. The reports also include recommended actions the facility may adopt to improve compliance with the applicable regulations. The facilities are required by Western Order 5482.1 to formally respond to the audit and correct the identified problems. The assistance of the environmental staff or contractors is made available to the Area Offices for help in achieving compliance through advice, or design and implementation of systems or structures.

\section{STATE AND LOCAL ENVIRONMENTAL REQUIREMENTS}

Western operates in 15 western and mid-western states. There has been an increasing trend in recent years for State, County, and local governments to apply environmental and siting controls and restrictions to Federal agencies as well as to private industry. Executive Order 12088 requires in many instances that Federal agencies must comply and coordinate with State and local environmental regulators.

Many states regulate the generation, transportation, treatment, storage, and disposal of hazardous and toxic materials. Community right-to-know legislation and hazardous waste cleanup laws were enacted in 1986 by numerous states as they attempt to control or track hazardous and toxic materials. Congress has also included provisions in many Federal environmental acts for states to become authorized to implement and manage the requirements of the acts. Examples of this are RCRA authorization, right-to-know, pesticide application, and underground storage tank regulations. 
Western cooperates with State and environmental regulators and works toward compliance with applicable laws, statutes, regulations, and ordinances. Environmental audits of Western facilities address the major State requirements in addition to those imposed by the Federal government.

\subsection{CULTURAL RESOURCES}

During 1986, Western initiated or continued previously initiated cultural resource compliance efforts for more than 35 undertakings in nine states. The undertakings included the construction of substations, microwave communication facilities, and electrical transmission lines. In accordance with Section 106 of the National Historic Preservation Act, as amended, Western solicited the comments of the President's Advisory Council on Historic Preservation regarding these undertakings by following the "Section 106" consultation process established in 36 CFR 800 . As part of its environmental planning process, Western consulted with the State Historic Preservation Officers in nine states in order to successfully inventory and evaluate cultural resources within the proposed project areas, to identify possible effects of the projects on significant cultural resources, and to develop and carry out plans to mitigate project effects on significant cultural resources.

Western's CRC program was initiated in 1983 when DOE authorized Western to designate an Historic Preservation Officer.

Western formalized its cultural resource compliance (CRC) program in 1986 and designated a CRC program manager to coordinate the program. This position augments the Historic Preservation Officer designated in 1983. 
In 1986, the President's Advisory Council on Historic Preservation revised 36 CFR Part 800: Protection of Historic Properties. Western provided comments on the proposed revisions to the Council. After the revised regulations were published in October 1986, Western's CRC program manager, environmental specialists, and cultural resource consultants attended workshops with the Council in order to incorporate the revised regulations into Western's overall environmental planning process.

\subsection{ENVIRONMENTAL PLANNING ACTIVITIES AND RESEARCH}

Table 3 lists the Environmental Impact Statements (EIS) and Environmental Assessments (EA) completed in calendar year (CY) 1986. As can be seen from the table, 6 EISs and 10 EAs were completed either to draft or final form in CY 1986. In addition, 17 Determination Memoranda were cleared in CY 1986.

Western has a list of standard mitigation measures (Appendix B) which accompany all transmission line construction contracts. This list has been developed over the years to ensure compliance with the National Environmental Policy Act (NEPA) and the Council on Environmental Quality (CEQ) guidelines and are based on Western's experience with typical transmission line construction, operation, and maintenance impacts throughout the 15-state service area.

Western continued initiating contacts in the early stages of projects with resource management and permitting agencies. 
TABLE 3

\section{ENVIRONMENTAL IMPACT STATEMENTS AND ENVIRONMENTAL ASSESSMENTS FOR CY 1986}

NAME

Conrad-Shelby TL'

Mead-Phoenix TL

Tucson Aqueduct Pumping Plant TL (Phase B)

Mead-Adelanto

Buffalo Bill TL

Post-1989 Marketing Plan

Blue River-Gore Pass TL

Kremmling Tap-Windy

Gap TL

Warren Air Force Base TL

Casper-Dave Johnston TL

City of Roseville

Interconnect

California-Oregon

Transmission Project

City of Redding

Interconnect

Collbran Rate Adjustment

CRSP Transmission Rate Adjustment

Rio Grande Rate

Adjustment

I $T L=$ Transmission Line
EIS

DRAFT FINAL

$11 / 86$

$--\quad 2 / 86$

$-\quad 1 / 86$

1/86

-- --

$-$

$--\quad 3 / 86$

-- $\quad--$

$--\quad-$

$--$

$6 / 86$

$6 / 86$

$-$

$8 / 86$

$12 / 86$

$-$

$-$

$11 / 86$

-- $\quad 3 / 86$

$-\quad 3 / 86$

$--$

$9 / 86$ 
In addition to the standard measures, Western frequently incorporates special mitigative techniques to address local environmental concerns. These may include special projects; visual simulation studies; endangered or threatened plant and/or animal surveys; and special studies of extraordinary environmental concerns, such as floodplains and wetlands or sensitive land use features. Some of these studies are listed in Table 4.

\section{PROJECTS}

Western had ten projects either started or underway during CY 1986. These projects, listed in Table 5, are either EISs or EAs and, except for one, are high voltage transmission lines.

\section{SPECIAL ENVIRONMENTAL ACTIVITIES AND RESEARCH}

\section{Environmental Workshop}

In April 1986, Western held a workshop for all Western and contract environmental specialists. This workshop was developed to keep the environmental specialists up to date on current problems and state-of-the-art solutions. Topics included National Historic Preservation Act compliance, preparation of determination memoranda, categorical exclusions, compliance with hazardous waste and toxic substances regulations, and management of cultural resources programs. 
TABLE 4

\section{SPECIAL MITIGATION MEASURES IMPLEMENTED BY WESTERN FOR \\ NATIONAL ENVIRONMENTAL POLICY ACT COMPLIANCE AND \\ FISH AND WILDLIFE COORDINATION ACT COMPLIANCE}

\begin{tabular}{|c|c|c|}
\hline STUDY & AREA & $\underline{\operatorname{DATE}(S)}$ \\
\hline $\begin{array}{l}\text { Endangered, Threatened, or } \\
\text { Special Plant Survey }\end{array}$ & CA & $1 / 86$ \\
\hline $\begin{array}{l}\text { Endangered and Threatened } \\
\text { Wildlife Survey }\end{array}$ & CA & $1,4,7 / 86$ \\
\hline Raptor Nesting Survey & $C A$ & $1 / 86$ \\
\hline Black-footed Ferret Survey & WY & $8-9 / 86$ \\
\hline Rare Plant Survey & co & $6-7 / 86$ \\
\hline Raptor Nesting Survey & $\mathrm{CO}$ & $5 / 86$ \\
\hline $\begin{array}{l}\text { Raised Height of Conductors } \\
\text { at Lake Crossing }\end{array}$ & ND & $4 / 86$ \\
\hline Special Shortened Structures & $A Z$ & $6 / 86$ \\
\hline $\begin{array}{l}\text { Installed Non-specular } \\
\text { Conductors }\end{array}$ & $A Z$ & $2 / 86$ \\
\hline $\begin{array}{l}\text { Raised Structure Height at } \\
\text { CAP Canals }\end{array}$ & $A Z$ & $4 / 86$ \\
\hline $\begin{array}{l}\text { Install Orange Globes for } \\
\text { Air Safety }\end{array}$ & $A Z / N V$ & $8 / 86$ \\
\hline $\begin{array}{l}\text { Install Orange Globes HVTL } \\
\text { to Reduce Bird Collisions }\end{array}$ & ND & $4 / 86$ \\
\hline $\begin{array}{l}\text { Special Study and Preparation } \\
\text { of Vegetation Management } \\
\text { Plan for HVTL ROW }\end{array}$ & $\mathrm{CO}$ & $8 / 86$ \\
\hline $\begin{array}{l}\text { Endangered and Threatened } \\
\text { Species Survey }\end{array}$ & $\mathrm{CO}$ & $6 / 86$ \\
\hline Visual Resource Management Plan & $\mathrm{co}$ & $6 / 86$ \\
\hline $\begin{array}{l}\text { Endangered and Threatened } \\
\text { Species Survey }\end{array}$ & $A Z$ & $5 / 86$ \\
\hline
\end{tabular}


TABLE 5

\section{PROJECTS ONGOING IN CY 1986}

PROJECT NAME

Charlie Creek-Belfield TL '

Jamestown-Grand Forks TL

Westwing-New Waddell TL

Liberty-Parker TL

Flatiron-Gunbarrel-Terry TL

Lovell-North Cody-Big George TL

Blue River-Summit TL

Seminoe-Kortes Switchyard

Lawrence Livermore TL

Craig-Bonanza TL
DATE STARTED

April 1986

November 1986

September 1985

July 1985

October 1986

January 1986

December 1985

March 1986

July 1985

December 1986

I $T L=$ Transmission Line 


\section{High-Voltage Direct Current Agricultural Study}

Western and eight other electrical transmission organizations are supporting a study to determine the possible effects of high-voltage direct current (HVDC) transmission lines on beef cattle and crops. In recent years, there has been an increased interest in the use of HVDC lines by the electric utility industry.

Oregon State University is the prime contractor for the research project. The Electric Power Research Institute is providing a panel of scientific advisors to assure the research is done correctly and without bias.

The primary objective of the research study is to determine if there are any significant effects of a $500-k V$ DC line on reproduction and production of beef cattle and wheat and alfalfa raised under controlled, simulated farming and ranching conditions. This work will supplement laboratory animal studies being done by other researchers. Planned to run for three years, the results of the first year showed no demonstrable effects on either the cattle or the crops.

\section{ENVIRONMENTAL PLANNING PERMITS}

Several environmental planning permits were obtained in CY 1986 for transmission line construction. These included a construction and surveying permit from the Gila River Indian Community for crossing Indian land in Arizona and "special status plant removal" permits from the State of Arizona for removing special status plant 
species from a high-voltage transmission line right-of-way. The plant removal permits are generally obtained by construction contractors. Additionally, special use permits were issued by the U.S. Forest Service and the Bureau of Land Management for construction of a transmission line and associated access roads and a microwave communication system in Colorado. 
APPENDIX A 
REPORT TO: U.S. DEPARTMENT OF ENERGY WESTERN AREA POWER ADMINISTRATION P 0 BOX 145

FORT PECK, MT 59223
DATE: January 24, 1986

JOB NUMBER: $85-945$

SHEET: $\quad 1$ OF

INVOICE NO:: 33996

REPORT OF: Groundwater Analysis - Miles City Converter Station

\section{Sample Identification:}

On November 4, 1985, these water samples were collected by our personnel and delivered to our laboratory for analysis. Tests were conducted in accordance with the U.S. Environmental Protection Agency Manual EPA 600/4-79-020, "Methods for Chemical Analysis of Water and Wastes" and other recognized methods. The results of the analysis appear on the following page. A minus sign indicates less than the reported value was present in the sample.

\section{TEST RESULTS:}

Lab No.:

Identification:

Date Sampled:

Collected by:

Ethylene Glycol, mg/l

Specific Conductance, umhos $/ \mathrm{cm}$

Nalco 8367 as Total Phosphorus as $P$

\author{
81585 \\ North Well \\ $11 / 14 / 85$ \\ Smit
}

$$
-100
$$

15,900

0.10
81587

East Well

$11 / 14 / 85$

Smit 


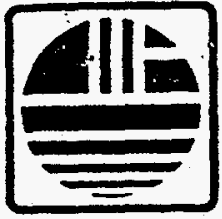

Engineering

and Testing. Inc.
600 South 25 th Street

P. O. BOx 30875

Billings, MT 59107

(406) $248-9161$
REPORT TO:

U.S. DEPARTMENT OF ENERGY

WESTERN AREA POWER ADMINISTRATION

$P$ O BOX 145

FORT PECK MT 59223
DATE: Apri1 17, 1986

JOB NUMBER: $85-945$

SHEET: 1 OF 1

INVOICE NO.: 34673

REPORT OF: Groundwater Analysis - Miles City Converter Station

\section{Sample Identification:}

On March 14, 1986, these water samples were collected by our personnel and delivered to our laboratory for analysis. Tests were conducted in accordance with the U.S. Environmental Protection Agency Manual EPA 600/4-79-020, "Methods for Chemical Analysis of Water and Wastes." The results of the analysis are shown below. A minus sign indicates less than the reported value was present in the sample.

TEST RESULTS:

Lab No.:

Sample Description:

$82896 \quad 82897 \quad 82898$

Date Sampled: West Well East Well North Well

Ethylene Glycol, $\mathrm{mg} / \mathrm{l}$ $3 / 13 / 86$ $3 / 13 / 86$ $3 / 13 / 86$

Specific Conductance,

umhos $/ \mathrm{cm}$

$-10$

$-10$

$-10$

15,500

14,700

15,500

Nalco 8367 as Total Phosphorus as $\mathrm{P}, \mathrm{mg} / \mathrm{T}$

0.21

0.03

Total Well Depth, ft.*

55.7

41.0

62.8

Depth to Water Surface, ft.*

* From top of casing

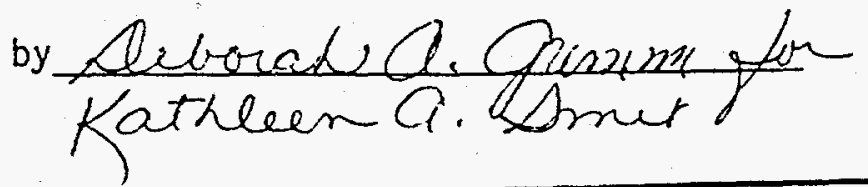

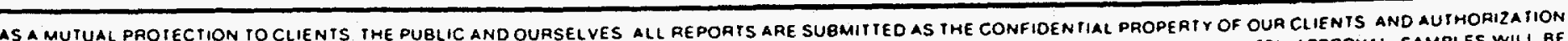

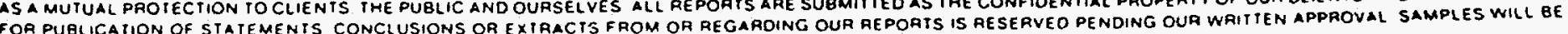
DISPOSEO OF AFIER TESIING IS COMPLETEOUNLESS OTHER ARRANGEMENTS ARE AGREED IOIN WRITING 
Engineering

and Testing. Inc.

REPORT TO:

DATE: July 28,1986

JOB NUMBER: $85-945$

U.S. DEPARTMENT OF ENERGY

WESTERN AREA POWER ADMINISTRATION

SHEET:

INVOICE NO.: 42522

P O BOX 145

FORT PECK MT 59223

REPORT OF: Groundwater Anatysis - Miles City Converter Station

Sample Identification:

On June 30, 1986, these water samples were delivered to our laboratory for analysis. Tests were conducted in accordance with the U.S. Environmental Protection Agency Manual EPA 600/4-79-020, "Methods for Chemical Analys is of Water and Wastes." The results of the analys is are shown below. A minus sign indicates less than the reported value was present in the sample.

TEST RESULTS:

Lab No.:

Sample Description:

85029

West Well

Date Sampled:

$6 / 30 / 86$

83030

North We17

85031

Ethylene GTycol, $\mathrm{mg} / \mathrm{l}$ $-10$

$6 / 30 / 86$

East We11

$6 / 30 / 86$
Specific Conductance, umhos $/ \mathrm{cm}$

12,200

11,700

11,600

Nạlco 8367 as Total

Phosphorus as $P, \mathrm{mg} / \mathrm{l}$

Total Well Depth, feet

0.11

0.19

0.34

55.7

62.8

41.0

$r m r$

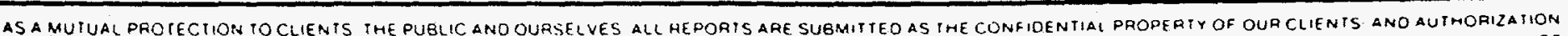

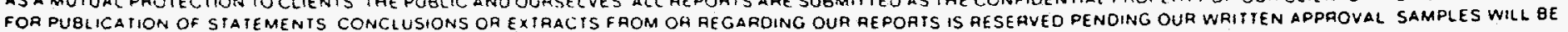
OISPOSED OF AFTEA IESTING IS COMPLETEO UNLESS OTHEA ARRANGEMENIS ARE AGREED TO IN WRITING 
REPORT TO:

\section{U.S. DEPARTMENT OF ENERGY WESTERN AREA POWER ADMINISTRATION P O BOX 145 \\ FORT PECK, MT 59223}

DATE: November 13, 1986 JOB NUMBER: $\quad 85-945$ SHEET: 1 OF 1 INVOICE NO: $\quad 46130$

REPORT OF: Groundwater Analysis - Miles City Converter Station

Sample Identification:

On October 13, 1986, these water samples were delivered to our laboratory for analysis. Tests were conducted in accordance with the U.S. Environmental Protection Agency Manual EPA 600/4-79-020, "Methods for Chemical Analysis of Water and Wastes." The results of the analysis are shown below. A < sign indicates less than the reported value was present in the sample.

TEST RESULTS:

Lab No.:

Sample Description: 86794

86795

Date Sampled:

East Well West Well $10 / 17 / 86 \quad 10 / 17 / 86$

85796

North Well $10 / 17 / 86$

Ethylene Glycol, mg/l $<20$

$<20$ $<20$

Specific Conductance, umhos $/ \mathrm{cm}$

Nalco 8367 as Total

Phosphorus as $P, \mathrm{mg} / \mathrm{l}$

0.21

0.11

0.16

Total Well Depth, ft.

Reviewed

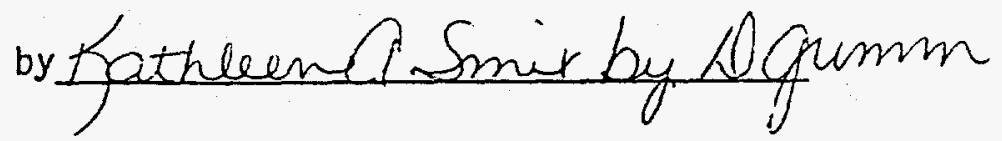

$r m r$ 
APPENDIX B 


\section{APPENDIX B}

Standard mitigative practices employed by the Western Area Power Administration to minimize impacts of transmission line construction and maintenance.

\section{$\underline{\text { Visual Resources }}$}

- Conductors may have a non-reflective finish to avoid sheen or a strong silhovette and to provide blending of the conductors into any given setting through which the line must pass.

- Western follows design practices identified in the "Environmental Criteria for Electric Transmission Systems" prepared by the U.S. Department of Agriculture and the U.S. Department of Interior and "National Forest Landscape Management, Volume 2, Chapter 2, "Utilities" prepared by the U.S. Department of Agriculture.

\section{Surface Water Protection}

- Structure sites and other disturbed areas are located at least 300 feet from rivers, streams (including ephemeral streams), ponds, lakes, and reservoirs, where practical.

- New access ways are located at least 300 feet from rivers, ponds, lakes, and reservoirs, where practical. 
- At crossings of perennial streams by new access ways, culverts of adequate size to accommodate the estimated peak flow of the stream are installed.

- Waste waters from concrete batching, or other construction operations, shall not enter streams, watercourses, or other surface waters without the use of turbidity control methods.

- Dewatering work for structure foundations or earthwork operations adjacent to streams or watercourses are conducted in a manner to prevent muddy water and eroded materials from entering the streams.

- Excavated material or other construction materials are not stockpiled or deposited near or on streambanks, lake shorelines, or other watercourse perimeters where they can be washed away by high water or storm runoff or can in any way encroach upon the actual watercourse itself.

\section{Vegetation Protection}

- Structures are carefully located to span narrow bands of sensitive vegetation conditions, including wetlands.

- Access ways are located to avoid sensitive vegetation conditions, including wetlands, or, if they are linear, to cross them at the least sensitive feasible point. 
- Removal of vegetation is minimized to avoid creating a swath along the right-of-way.

- Structures are located and designed to conform with the terrain. Leveling and benching of the structure sites will be the minimum necessary to allow structure assembly and erection.

\section{Wildlife Protection}

- Construction activities are timed to reduce impacts to wildlife during periods when human disturbance may unduly stress populations. These include critical winter or summer periods, birthing periods, or other periods of high sensitivity. 


\section{REFERENCES}

Clean Water Act

Comprehensive Environmental Response Compensation and Liability Act

Department of Energy Organization Act of 1977 (P.L. 95-91)

DOE Order 5480.1

DOE Order 5484.1

Endangered Species Act of 1973 (16 U.S.C. 1531 et seq.)

Executive Order 12088

Federal Insecticide, Fungicide, and Rodenticide Act

Federal Water Pollution Control Act

Fish and Wildlife Coordination Act (16 U.S.C. 661-666c)

Hazardous and Solid Waste Amendments of 1984

National Environmental Policy Act of 1969 (42 U.S.C. $4321-4347$ )

National Historic Preservation Act of 1966, as Amended

Resource Conservation and Recovery Act

Superfund Amendments and Reauthorization Act of 1986

Western Area Power Administration Order 5480.1 


\section{DISTRIBUTION}

Office of Environmental Guidance and Compliance, $\mathrm{EH}-23$

DOE Scientific and Technical Information Center

Boulder City Area Office, Western Area Power Administration

Billings Area Office, Western Area Power Administration

Sacramento Area Office, Western Area Power Administration

Loveland Area Office, Western Area Power Administration

Salt Lake City Area Office, Western Area Power Administration

Headquarters, Western Area Power Administration

A0000

$\mathrm{A} 0100$

$\mathrm{A} 0200$

A 1000

A2000

A 6000 